ume, which is a copy of The Cromwell Bible. Attendees also signed the Libraries Guest Book, which was first signed by Franklin Delano Roosevelt in 1936 at the dedication of Temple's first library building.

\section{WESS Martinus Nijhoff Study Grant for 2002 postponed}

Swets Blackwell has postponed the 2002 ACRL West European Specialist Section (WESS)/ Martinus Nijhoff International Study Grant after acquiring Martinus Nijhoff International, the grant's sponsor. An announcement about the grant's future is expected upon the com- plete integration of the two companies in the spring of 2002.

For further information about other ACRL award opportunities, visit http://www.ala.org/ acrl/award2.html or contact ACRL Awards Program Assistant, Stephanie Sherrod at (312) 280-2515, e-mail: ssherrod@ala.org.

\section{NEH Challenge Grant for local history}

NEH has announced a special initiative to support the local history efforts of organizations with activities and collections vital to the history of a locality. Challenge grants will

\title{
Thoughts about the library, librarians, and our hopes and fears
}

Editor's note: The following message from Sidney Verba, Carl H. Pforzheimer University Professor and director of the Harvard University Library, appeared on that library's Web site. We are reprinting it with permission as an aide to sustaining and inspiring us during these difficult times.

When the horror of September 11 burst upon us, I was writing something for a different purpose on the complexity of the work of libraries and librarians in our multimedia digital age. It was for a non-library audience and what was said would sound familiar to all of us in the library. I used the 2000 presidential election as an example of the latest news in many media that our libraries would capture for history.

Then came the attack, and those words about libraries and the election seemed trivial. Reversing Marx, history moved from farce to tragedy.

All of us these past weeks have wondered about many things. We have been at meetings, we have gone about our work, we have chatted with friends, we have walked across the campus in the early morning sunlight-and in all of these ordinary moments of life, we have felt that they were somehow unreal, that the foundation of life, of the good things in life, was gone. Some said, "Welcome to the new century." It began on September 11 in Lower Manhattan.
For a while, death and destruction may have made many of us feel that the work we do is somehow irrelevant; not worth the attention and value we give it. That, we know, is wrong. Terrorists last week tried to destroy our way of life by taking lives. We mourn, but life goes on and must go on.

The work of the library becomes more meaningful, more important. Libraries are the most humane of human institutions; the opposite of terrorist cells. Libraries are gentle, benevolent. They celebrate the best of what we are. True, they do contain the history of human folly and of human evil, as they will contain the history of recent weeks. Terrorism is one of the most inhumane and uncivilized of all acts. But capturing the history of it-like capturing the history of all we humans do (good and bad)-is one of the most humane and civilized of activities. It allows us to remember, to learn, and to pass on that memory and learning to new generations.

Memory and learning are two of the most cherished of human abilities. In the midst of our sadness we must remember that. The terror attack tore our world apart, but it also connected us to many people we did not know. "Only connect."

Never forget.

We will preserve the connections and the memories. 